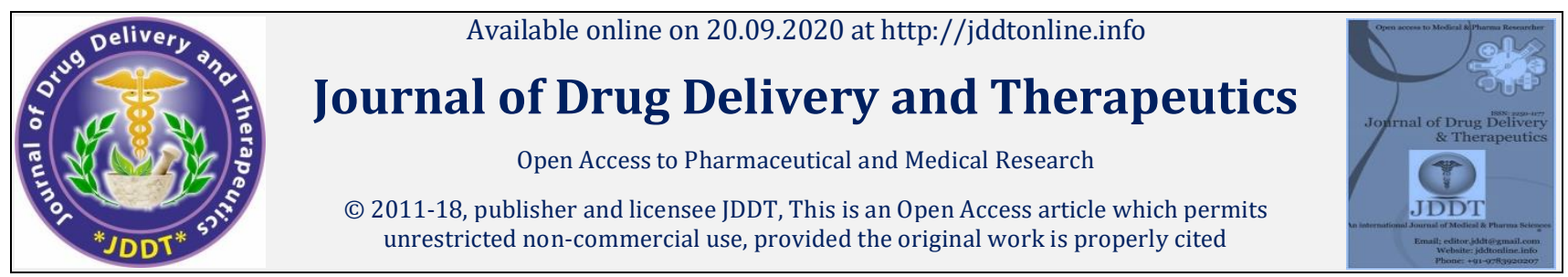

Open $\odot$ Access

Review Article

\title{
A Review on Herbal Plants used in Brain Ischemic and Reperfusion Injury
}

\author{
Simran Singh 1*, Shayan Shafi', Alankar Shrivastav ${ }^{2}$, Shahbaz Khan ${ }^{2}$, Tanzeel Ahmad ${ }^{3}$, Najam Ali khan ${ }^{1}$ \\ ${ }^{1}$ Department of Pharmacology, School of Pharmaceutical Science, IFTM University, Moradabad, India \\ 2 Department of Pharmacology, Pharmacy Academy, IFTM University, Moradabad, India \\ ${ }^{3}$ School of Biotechnology, IFTM University, Moradabad, India
}

\begin{abstract}
A stroke causes serious and long term brain disability due to disruption in the blood flow to the brain. Clinically major changes occur in brain functions are seen after brain ischemia and reperfusion. Patients show emotional, behavioural, and cognitive alterations during retrieval time. Cerebral injury by transient ischemia distresses the number of patients globally with death or long term disability. In recent years a great deal of research has been carried out to find the effectiveness of the herbal drug for the treatment of stroke. Both thrombolytic and neuro-protective activities of herbal drugs may be a new strategy for effective stroke treatment. This article reviews the list of universally used plants effective for brain stroke therapies. The purpose of this article was to collect the herbal drugs useful in brain stroke therapies.
\end{abstract}

Keywords: ischemia-reperfusion, brain injury, stroke, herbal drugs, tissue

Article Info: Received 09 July 2020; Review Completed 22 August 2020; Accepted 08 Sep 2020; Available online 20 Sep 2020

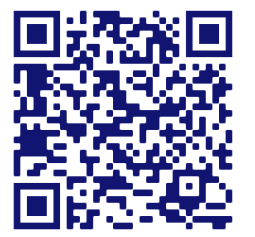

Cite this article as:

Singh S, Shafi S, Shrivastav A, Khan S, Ahmad T, Khan NA, A Review on Herbal Plants used in Brain Ischemic and Reperfusion Injury, Journal of Drug Delivery and Therapeutics. 2020; 10(5):376-379

http://dx.doi.org/10.22270/jddt.v10i5.4415

Simran Singh, Department of Pharmacology, School of Pharmaceutical Sciences, IFTM University, Moradabad, India

\section{Introduction}

A stroke is a medical condition in which flow of blood is poor to the brain results in cell death. Stroke plays a central role in public health. More than $80 \%$ of all stroke events is due to ischemic stroke, causing a transient or permanent reduction in cerebral blood flow. Most of the cases are caused by thrombotic occlusions. 600,000 people suffering from stroke every year with serious, long-range disability by stroke 1. Difficulties like Memory, thinking, talking, and partial paralysis and mobility problems caused by stroke 2 . Ischemia-reperfusion injury is a condition in which physicians control the damage to cells and organ preservation for the function of tissue and organ during storage so that the graft will function at re-perfusion. Ischemia is defined as the reduced amount of blood flow (hypoperfusion) of tissue. Tissue hypoperfusion may cause various conditions, like sepsis, acute coronary syndrome, organ transplantation and limb injury; studies suggested that reducing the time of blood flow to preserve the function of tissue and organ. Stroke is the rapid development of focal and global disorder of brain function, with various symptoms that can earlier more than $24 \mathrm{~h}$ or cause death, with no obvious cause other than the vascular origin ${ }^{3}$. Intravenous recombinant tissue plasminogen activator (rt-PA) is the only drug used for the thrombolytic treatment of acute ischemic stroke. rt-PA decreases neurological injury and enhances the functional outcome of stroke survivors. Only $6 \%$ of patients are survivors, many patients with brain stroke do not reach the hospital within time, that's why most patients do not receive rt-PA treatment 4.

Neutrophils utilize the vicious capabilities of free radicals to kill the bacteria, and there is confirmation that they also act on reper fused tissue. Morphological injury to the muscle fibers was evident only after reperfusion. Muscles biopsies showed that infiltration with granulocytes, mainly neutrophils, throughout ischemia and reperfusion and enhance the number of circulating neutrophils. It confirmed that neutrophils entered the cardiac tissue during reperfusion. Ischemia may accumulate neutrophils in such numbers that they block the microvasculature 5 and also seems to be associated with endothelial damage and also part of the inflammatory response, coordinated by a network of inflammatory cytokines and chemokines that is not absolutely understood. A rat leg model of ischemia/reperfusion is used to study the kinetics of cytokine production by some scientist. Reperfusion 
increased markedly the level of IL-1, TNF-alpha and IL-6. TNF-alpha and IL-1 level reach at high after two hours and IL-6 continued to rise throughout the four hour recording period. Additionally, the amount of damage to both the leg muscles and the lungs was decreased significantly by antibodies to IL-1 and TNF, by IL-1 receptor antagonist and by soluble TNF receptor. Where large volumes of tissue are reperfused, as in this study, the post-ischemic syndrome may develop. There are many features with the systemic inflammatory response syndrome (SIRS) that occurs in sepsis, as well as respiratory and other organ disorder, and it is in the same way related with an increased level of inflammatory cytokines in the systemic circulation. Further move towards decreasing neutrophil-mediated reperfusion injury is to reduce neutrophil infiltration of the ischemic tissue. Adhesion molecules are essential for neutrophils to extravasate, and numerous studies have shown that the levels do certainly increase during ischemia/reperfusion. As a result, antibodies to adhesion molecules, including ICAM1 and P-selectin, have been tried as possible therapies in animals, with significant success. A selectin blocker that binds to the neutrophil ligand for both E- and P-selectin also decreased infarct size 6.

Presently, there are no clear cut therapies as per studies of reperfusion injury and attempts to control it. Probably due to a variety of experimental protocols, none of the potential therapies to bound the production of free radicals on reperfusion has been constantly advantageous in controlled trials. The association of inflammatory cytokines and their effects on neutrophils is a relatively current discovery, and it opens a new possibility for investigation. Conceivably in the longer term, better techniques for fast reperfusion with the use of anti-oxidants and neutrophil inhibitors will cut the massive cost.

\section{Pathogenesis of Brain Ischemia-reperfusion}

In brain, intracellular cell death signalling pathways may lead to the death of cells due to ischemia ${ }^{7}$. Reduced cerebral blood circulation in the region of the brain that is comfortable with oxygen by the occluded vessels in case of focal/global cerebral ischemia [7]. Ischemia and postischemic reperfusion injured brain capillaries result in a progressive alteration in the permeability of the blood-brain barrier (BBB) that can later consequence in the development of edema and hemorrhagic conversion. Substances such as $\mathrm{Na}^{+}$, water, serum proteins, and blood infiltrate into the extracellular space of the brain tissue and cause swelling in case of changing the BBB permeability 8-10. Swelling is deadly for cerebral tissue as its effects on neighbouring tissues are also magnified by the proper volume of the skull. Swelling of cerebral tissue induced by brain ischemia and reperfusion apply an involuntary force on the nearby shell of brain tissues, displacing it and causing ever-increasing tissue pressure within it. The pressure of brain tissue exceeds capillary pressure; increased capillary infiltration is compromised and cause ischemia and development of edema 11 .
The use of glucose in the brain is rise considerably during brain ischemia, by the dependence of brain on anaerobic glycolysis, due to this brain glucose levels fall rapidly, in spite of near-normal plasma levels 12. A complex cascade of metabolic events initiated during brain ischemia and reperfusion, most of involve in the manufacture of nitrogen and oxygen-free radicals. These free radicals arbitrate more damages that occur subsequent transient brain ischemia 13 . The diminish in cerebral blood flow and oxygen consumption initiates a cascade of harmful biochemical actions during brain ischemia. Decrease of oxygen precludes oxidative phosphorylation and consequence in anaerobic metabolism 14. The mitochondrial respiratory chain is the origin for the formation of reactive oxygen species (ROS) and following the damage of the mitochondria, necrotic cell death occurs. Death of endothelial cells causes harm to blood-brain barrier resulting in cerebral edema 15. Failure of transcellular ion pump outcomes in the intracellular accumulation of $\mathrm{Na}^{+}$, $\mathrm{Ca}^{2+}$ and water. The membrane depolarization results in the release of excitatory neurotransmitters from axon terminals. The glutamate then activates specific cell surface receptors resulting in an influx of $\mathrm{Na}^{+}$and $\mathrm{Ca}^{2+}$ into postsynaptic neurons. In neurons, the intracellular calcium induces the production of nitric oxide (NO) that diffuses to adjacent cells susceptible to nitric oxide toxicity. When NO attach with superoxide the proxy nitrites have formed that lead to lipid peroxidation 16. Impermeability of the blood-brain barrier is maintained by tight junctions and basal lamina of microvascular endothelial cells. During the first hours of ischemia, dissolution of the endothelial basal lamina starts 17 .

The traditional medicine all over the globe is at the present time revalued by an extensive performance of the research on the different plant species and their potential. Herbal drugs have gained a lot of approval in recent years just because they have higher therapeutic potential, minute side effects and economically. Herbs may afford a source of various types of new compounds including many drugs that are derived from plant sources.

\section{Conclusion}

Herbal drugs play a vital role in the management of deadly neurological diseases. As brain stroke is a complex progressive injury relating to numerous mechanisms. The progress of neuroprotective agents from the herbal plant is a promising way in the treatment of brain stroke and related neurodegenerative diseases. In the future, more concentration should be paid to herbal compounds that can slant the BBB and have broad therapeutic time windows, accurate pharmacological targets and lesser side effects.

\section{Conflict of interest statement}

We declare that we have no conflict of interest.

\section{Acknowledgments}

Authors are thankful to Director, School of Pharmaceutical Sciences, IFTM University, Moradabad (U.P) for motivation and facilities provided to conduct this work. 
List of plants on which study has been done:

\begin{tabular}{|c|c|c|c|c|c|c|}
\hline $\begin{array}{l}\text { S. } \\
\text { No. }\end{array}$ & Name of the plant & Family & Common name & $\begin{array}{l}\text { Plant } \\
\text { part } \\
\text { used }\end{array}$ & $\begin{array}{l}\text { Extracts } \\
\text { studied }\end{array}$ & References \\
\hline 1. & Gastrodia elata & Orchidaceae & Tianma & $\begin{array}{l}\text { Herb } \\
\text { Herb }\end{array}$ & $\begin{array}{l}\text { Ethanolic } \\
\text { extract }\end{array}$ & $\begin{array}{l}\text { Jivad N, Rabiei Z et al., } \\
\text { 2015. } 18 \\
\text { Wang D et al., } 201919\end{array}$ \\
\hline 2. & Ginkgo biloba $L$ & Ginkgoaceae & Maidenhair tree & Herb & $\begin{array}{l}\text { Ethanolic } \\
\text { extract }\end{array}$ & $\begin{array}{l}\text { Jivad N, Rabiei Z et al., } \\
\text { 2015. } 18\end{array}$ \\
\hline 3. & Panax ginseng & Araliaceae & Korean ginseng & Roots & $\begin{array}{l}\text { Ethanolic } \\
\text { extract }\end{array}$ & Shamim M et al., 201920 \\
\hline 4. & Anchusa & Boraginaceae & Bugloss & Flower & Ethanolic & Torki A et al., $2018^{21}$ \\
\hline 5. & Danshen and Gegen & Lamiaceae & $\begin{array}{l}\text { Red sage, Chinese sage } \\
\text { or Tan shen }\end{array}$ & Herb & Ethanolic & Deng Y et al., 201822 \\
\hline 6. & Lavandulaofficinalis & Lamiaceae & English Lavender & Herb & $\begin{array}{l}\text { Lavender } \\
\text { oil }\end{array}$ & $\begin{array}{l}\text { Jivad N, Rabiei Z et al., } \\
2015.18\end{array}$ \\
\hline 7. & Withaniacoagulans & Solanaceae & Indian cheese maker & Roots & $\begin{array}{l}\text { aqueous } \\
\text { extract }\end{array}$ & $\begin{array}{l}\text { Sagheb H M et al., } 2017 \\
23\end{array}$ \\
\hline 8. & Vitisvinifera & Vitaceae & Grape & Fruit & Ethanolic & Sarkaki A et al., $2016^{24}$ \\
\hline 9. & $\begin{array}{l}\text { Bacicalin \& } \\
\text { Jasminoidin }\end{array}$ & $\begin{array}{l}\text { Lamiaceae \& } \\
\text { Rubiaceae }\end{array}$ & $\begin{array}{l}\text { Cape jasmine, } \\
\text { Gardenia }\end{array}$ & $\begin{array}{l}\text { Root \& } \\
\text { Fruit }\end{array}$ & Ethanolic & $\begin{array}{l}\text { Jivad N, Rabiei Z et al., } \\
\text { 2015. } 18\end{array}$ \\
\hline 10. & Oil of O .europaea & Oleaceae & Wild olive, Indian olive & Leaf & Olive oil & $\begin{array}{l}\text { Jivad N, Rabiei Z et al., } \\
2015^{18}\end{array}$ \\
\hline 11. & Nigella sativa & Ranunculaceae & $\begin{array}{l}\text { Black caraway or } \\
\text { Kalonji }\end{array}$ & Leaf & Aqueous & $\begin{array}{l}\text { Hobbenaghi R et al., } \\
201425\end{array}$ \\
\hline 12. & Camellia sinensis & Theaceae & $\begin{array}{l}\text { Tea shrub, } \\
\text { Tea tree }\end{array}$ & $\begin{array}{l}\text { Leaf } \\
\text { Leaf }\end{array}$ & Green tea & $\begin{array}{l}\text { Jivad N, Rabiei Z et al., } \\
2015.18 \\
\text { Chakraborty M et } \\
\text { al.,2014.26 }\end{array}$ \\
\hline 13. & Rosa laevigataMichx & Rosaceae & Cherokee rose & Fruit & $\begin{array}{l}\text { Flavonoid } \\
\text { rich-extract }\end{array}$ & Zhang S et al., 2013.27 \\
\hline 14. & Punicagranatum & Punicaceae & Anar & Seeds & $\begin{array}{l}\text { Hydro- } \\
\text { alcoholic }\end{array}$ & Sarkaki A et al., 2013. 28 \\
\hline 15. & Zingiberofficinale & Zingiberaceae & Ginger & Fruit & Aqueous & Jittiwat J et al., 2012. ${ }^{29}$ \\
\hline 16. & Apocynumvenetum & Apocynaceae & Sword-leaf dogbane & Leaf & $\begin{array}{l}\text { Hydro- } \\
\text { alcoholic }\end{array}$ & Xiang j et al., 2012.30 \\
\hline 17. & Ocimum sanctum & Lamiaceae & Holy basil or Tulsi & Leaf & Fresh juice & $\begin{array}{l}\text { Jivad N, Rabiei Z et al., } \\
\text { 2015. } 18\end{array}$ \\
\hline 18. & Ocimumbasilicum & Lamiaceae & $\begin{array}{l}\text { Sweet basil, Common } \\
\text { basil, Thai basil. }\end{array}$ & Leaf & $\begin{array}{l}\text { Ethyl } \\
\text { acetate }\end{array}$ & $\begin{array}{l}\text { Jivad N, Rabiei Z et al., } \\
2015.18\end{array}$ \\
\hline 19. & Artemisia absinthium & Asteraceae & $\begin{array}{l}\text { Worm wood, Grand } \\
\text { worm wood }\end{array}$ & Herb & Ethanolic & $\begin{array}{l}\text { Jivad N, Rabiei Z et al., } \\
\text { 2015. } 18\end{array}$ \\
\hline 20. & Oleaeuropaea & Oleaceae & $\begin{array}{l}\text { Wild olive, Indian } \\
\text { olive, Brown olive }\end{array}$ & Leaf & Olive leaf & $\begin{array}{l}\text { Jivad N, Rabiei Z et al., } \\
\text { 2015. } 18\end{array}$ \\
\hline
\end{tabular}




\section{References}

1) Krause GS, Kumar K, White BC, Aust SD, Wiegenstein JG. Ischemia, resuscitation, and reperfusion: mechanisms of tissue injury and prospects for protection. Am Heart J 1986; 111(4):768-80.

2) White BC, Sullivan JM, DeGracia DJ, O'Neil BJ, Neumar RW, Grossman LI, et al. Brain ischemia and reperfusion: molecular mechanisms of neuronal injury. J Neurol Sci 2000; 179(S 12):1-33.

3) Lo EH, Dalkara T, Moskowitz MA. Mechanisms, challenges and opportunities in stroke. Nat Rev Neurosci 2003; 4(5):399-415.

4) Donnan GA, Davis SM, Parsons MW, Ma H, Dewey HM, Howells DW. How to make better use of thrombolytic therapy in acute ischemic stroke. Nat Rev Neurosci 2011; 7(7):400-9.

5) Formigli, L. et al. Human Path. 1992; 23:627

6) Silver, M.J. et al. Circulation 1995; 92:492.

7) Chan $\mathrm{PH}$. Reactive oxygen radicals in signaling and damage in the ischemic brain. J Cereb Blood Flow Metab 2001; 21(1):2 14.

8) Joo F, Klatzo I. Role of cerebral endothelium in brain oedema. Neurol Res 1989; 11(2):67-75.

9) Betz AL, Iannotti F, Hoff J. Brain edema: a classification based on blood-brain barrier integrity. Cerebrovasc Brain Metab Rev 1988; 1(2):133-54.

10) Ayata C, Ropper AH. Ischaemic brain oedema. J Clin Neurosci 2002; 9(2):113-24.

11) Hossmann KA, Schuier FJ. Experimental brain infarcts in cats. I. Pathophysiological observations. Stroke 1980; 11(6):583-92.

12) Vannucci RC, Yager JY, Vannucci SJ. Cerebral glucose and energy utilization during the evolution of hypoxic-ischemic brain damage in the immature rat. J Cereb Blood Flow Metab 1994; 14(2):279-88.

13) Love S. Oxidative stress in brain ischemia. Brain Pathol 1999; 9(1):119-31

14) Wyatt JS, Edwards AD, Azzopardi D, Reynolds EO. Magnetic resonance and near infrared spectroscopy for investigation of perinatal hypoxic-ischaemic brain injury. Arch Dis Child 1989 64(7 Spec No):953-63.

15) Cunningham LA, Wetzel M, Rosenberg GA. Multiple roles for MMPs and TIMPs in cerebral ischemia. Glia 2005; 50(4):32939.

16) Shalak L, Perlman JM. Hypoxic-ischemic brain injury in the term infant-current concepts. Early Hum Dev 2004; 80(2):125-41.

17) Gasche Y, Copin JC, Sugawara T, Fujimura M, Chan PH. Matrix metalloproteinase inhibition prevents oxidative stressassociated blood-brain barrier disruption after transient focal cerebral ischemia. J Cereb Blood Flow Metab 2001; 21(12):1393-400

18) Jivad N, Rabiei Z. Review on herbal medicine on brain ischemia and reperfusion. Asian Pacific Journal of Tropical Biomedicine.2015; 10.1016/j.
19) Wang D, Wang Q, Chen R, Yang S, Li Z, FengY. Exploring the effects of Gastrodia elata Blume on the treatment of cerebral ischemia-reperfusion injury using UPLC-Q/TOF-MS-based plasma metabolomics. The Royal Society of Chemistry. 2019 10.1039/c9fo01729a.

20) Shamima M, Khana NI. Neuroprotective effect of Panax ginseng extract against cerebral ischemia- reperfusion-injuryinduced oxidative stress in middle cerebral artery occlusion models. FACETS 2019 4:52-68 DOI: 10.1139/facets-20180025.

21) Akram Torki, Valiallah Khalaji-Pirbalouty, Zahra Lorigooini Mahmoud Rafieian-Kopaei, Arezo Sadeghimanesh and Zahra Rabiei. Anchusa italica extract: phytochemical and neuroprotective evaluation on global cerebral ischemia and reperfusion. Braz. J. Pharm. 2018 Sci. vol.54 no.1 São Paulo.

22) Deng Y, Lam FFY, Ng ESK, Lau CBS, Koon JCM, Leung PC and Fung KP. A Herbal Formulation of Danshen and Gegen Protects Rat Brains from Injuries Induced by Focal and Global Ischaemia. ScholArena 2018, 1:104.

23) Hamidreza Mahmoudzadeh-Sagheb, Zahra Heidari and Maryam Sarbishegi. Withania coagulans Protects Striatum from Oxidative Damages Induced by Global Brain Ischemia in Rat. Jundishapur J Nat Pharm Prod. 2018; 13(2):e65051.

24) Sarkaki A, Rafieirad M, Hossini SE, Farbood Y, Mansouri SMT, et al. Cognitive deficiency induced by cerebral hypoperfusion/ischemia improves by exercise and grape seed extract. Health Med 2012; 6(4):1097-1104.

25) Hobbenaghi R, Javanbakht J, Sadeghzadeh S, Kheradmand D, Abdi F, et al. Neuroprotective effects of Nigella sativa extract on cell death in hippocampal neurons following experimental global cerebral ischemia-reperfusion injury in rats. J Neurol Sci 2014; 337(1-2):74-79.

26) Chakraborty M, Kamath JV. Pharmacodynamic interaction of green tea extract with hydrochlorothiazide against ischemiareperfusion injury-induced myocardial infarction. J Adv Pharm Technol Res. 2014; 5(3):134-139.

27) Zhang S, Qi Y, Xu Y, Han X, Peng J, et al. Protective effect of flavonoid-rich extract from Rosa laevigata Michx on cerebral ischemia-reperfusion injury through suppression of apoptosis and inflammation. Neurochem Int 2013; 63(5):522-532.

28) Sarkaki A, Hajipour S, Mansouri MT, Pilevarian A, Rad MR Pomegranate seed hydroalcoholic extract improves memory deficit due to permanent cerebral hypoperfusion/ischemia in male rats. Health Med 2013; 7(3): 863-871.

29) Jittiwat J, Wattanathorn J. Ginger pharmacopuncture improves cognitive impairment and oxidative stress following cerebral ischemia. J Acupunct Meridian Stud. 2012; 5(6):295-300.

30) Xiang J, Lan R, Tang YP, Chen YP, Cai DF. Apocynum venetum leaf extract attenuates disruption of the blood-brain barrier and upregulation of matrix metalloproteinase-9/-2 in a rat model of cerebral ischemia-reperfusion injury. Neurochem Res. 2012; 37(8):1820-1828. 